\title{
The History Behind the Mechanics of Oral Appliance Therapy for the Treatment of Obstructive Sleep Apnea
}

\author{
B. Gail Demko, DMD, D.ABDSM \\ Sleep Apnea Dentists of New England, Newton Centre, MA
}

The past actually happened, but history is only what people wrote down.

A. Whitney Brown The Big Picture

\begin{abstract}
When studying history for the roots of knowledge, one can only go back to the first time that an idea was written down. This does not necessarily mean that the author of that prose was the innovator, only that the author was committing to paper an idea, common knowledge, or belief present at that time. Some authors take a piece of knowledge and are able to bring that idea to a wide audience, spreading ideas and thoughts far from the point of origin. This first in a series of papers hopes to acquaint the reader with the long history behind oral appliance therapy for the treatment of obstructive sleep apnea.
\end{abstract}

Keywords: jaw thrust, tongue extension, history, von Esmarch, chloroform, resuscitation, oral appliance, obstructive sleep apnea, obstructive sleep apnea treatment

Citation: Demko, BG. The history behind the mechanics of oral appliance therapy for the treatment of obstructive sleep apnea. $J$ Dent Sleep Med. 2019;6(1)

\section{INTRODUCTION}

\section{History repeats itself. Historians repeat each other. Philip Guedalla}

Although it is possible that some procedures in medicine are completely new, more often they are rediscoveries of techniques from the past. This first article looks at the history of the jaw-thrust and tongue extension maneuvers that provide the basis of oral appliance therapy (OAT) for the treatment of obstructive sleep apnea (OSA) and snoring.

The history of OAT for the treatment of OSA is based in centuries of scientific experimentation and advancements. None of the concepts required for dentists to treat this potentially dangerous disease are new. They come to current practitioners through their medical training, "common knowledge", and shared experience. In medicine, entirely new ideas are rare, but rediscoveries are common. This segment of OAT history looks at the concepts of jaw advancement and tongue extension that have existed for almost 200 years and briefly discusses what went before.

The idea of the four humors being the source of health and illness dominated Western medicine for 2,000 years; disease was thought to be the result of an imbalance of the four elements: yellow bile, black bile, phlegm, and blood. ${ }^{1-}$ 3 Although advances in physiology, microbiology, and chemistry in the 19th century eventually discredited the humoral theory in Western medicine, treatment of airway obstruction during these early years involved both active mechanical intervention coupled with the standard humoral approach of bleeding, cupping, and using stimulants or emetics.

The initial concept of reviving or resuscitating a person who was not breathing is lost in the distant past. Early treatment of airway obstruction addressed closure of the airway caused by trauma, infection, foreign bodies, drowning, and stillbirth. Mechanical interventions (insufflation by direct pressure or manipulation of the rib cage and tracheostomy) as well as humoral balancing have been described for millennia.

\section{To understand a science, it is necessary to know its history. \\ Auguste Comte}

\section{BEFORE THE MID $19^{\text {TH }}$ CENTURY}

Many historians harken back to biblical times and quote 2 Kings 4:34-35 ${ }^{4}$ as evidence that artificial respiration/ resuscitation had been practiced for millennia.

34. He went to the bed and lay on the boy, putting his mouth on the boy's mouth, his eyes on the boy's eyes, and his hands on the boy's hands. He stretched himself out on top of the boy. Soon the boy's skin became warm. 35. Elisha turned away and walked around the room. Then he went back and put himself on the boy again. The boy sneezed seven times and opened his eyes.

Although this reference may be taken as implying 
some sort of mouth-to-mouth respiration, it is far from strong evidence. (Others believe that Elisha actually caused compression of the rib cage by 'throwing himself' on the child, indicating mechanical resuscitation). ${ }^{5}$ Ancient Egyptians are also cited in attempts to restore respiration. Other active mechanical techniques for resuscitation throughout millennia have included hanging a person by the feet (inversion technique), rolling the victim over a barrel, rocking the person on a teeter board, and carrying the person face down on the back of an ox. ${ }^{5}$

Stimulants and irritants were used to urge the muscles into action. Some were verbal, such as yelling and shouting at the victim to waken; others were physical, such as rubbing the skin, injecting tobacco juice into the rectum or snuff into the nose, shining a bright light into the eyes, placing hot coals on the abdomen, or injecting into the stomach or bowel strong camphorated oils, peppermint, nutmeg, or emetics. ${ }^{6}$ These recommendations for resuscitating drowning victims were translated into most European languages by $1773 .{ }^{5}$ Rubbing the skin continued into Victorian times, such as rubbing the wrists of women who had fainted. It seems reasonable to add a jab from a bed partner's elbow to this category.

Instances of insufflation of air into the lungs of drowning victims or those overcome by noxious gases appear throughout history. Use of positive pressure for resuscitation in the 17th and 18th century (in Europe) involved the use of a bellows placed in the mouth or nose of a drowning victim, a technique originally credited to Swiss-born Paracelsus in the 16th century. ${ }^{7}$ In 1667 , the physiologist Robert Hooke, MD was able to keep a dog alive for more than an hour by using a bellows to provide air to the lungs via a tracheostomy. ${ }^{7}$ Mouth-to-mouth resuscitation was described in 1744, when William Tossach wrote a report about resuscitating a man who had been overcome by noxious gases and smoke in a mine. In this publication, Mr. Tossach reports "I applied my mouth close to his, and blowed as strong as I could...raising his chest fully with it." 8 In addition to mouth-to-mouth resuscitation, Tossach also pulled, pushed, and rubbed the body to assist the motion of the blood, washed the victim's face with water, rubbed sal volitale (smelling salts) on his nose and lips and bled him from his arm. ${ }^{8}$ Later in the 18th century, John Fothergill, a devotee of Tossach, reported that "bleeding ....and chafing, rubbing, pulling; the application of stimulants [to the victim] are too often ineffectual. The method of distending the lungs of person, dead in appearance, having been tried with such success in one instance, gives just reason to expect, that it may be useful to others." ${ }^{\text {In }} 1770$, mouth-to-mouth resuscitation was reported superior to the use of bellows by the French Academy of Sciences. Nevertheless, the idea of mechanical rubbing, rocking, and splashing the victim's face with cold water was well ingrained in popular culture and continued throughout the 19th century. ${ }^{7}$
The history of tracheostomy is better known. Although Galen reported that the procedure was first performed by Asclepiades of Bithynia (a Roman province in Asia Minor) around $100 \mathrm{BC},{ }^{10}$ the procedure was described earlier by ancient Egyptian physicians to relieve high respiratory obstructions. ${ }^{11}$ It was rarely successful and was periodically denounced and revived as a medical procedure throughout history. The Talmud, a compendium of Judaic cultural life and legal commentary on the Torah, contains a description of inserting a reed through the trachea to assist breathing in newborns. ${ }^{12}$ Although many physicians knew about the procedure, the decision to implement such a radical therapy was fraught with indecision. It is commonly believed that the first president of the United States, George Washington, died of upper airway obstruction caused by bacterial epiglottitis. ${ }^{13}$ He slowly suffocated while the physicians attending him tried to decide whether to do a tracheostomy or continue bloodletting. ${ }^{14}$ The first successful tracheostomy in modern times was credited to Pierre-Fidèle Bretonneau, MD in $1825 .{ }^{15}$

In the 18th century, John Fothergill promulgated the use of electric stimulation as did John Kite. ${ }^{6}$ Use of electrical shock should be "administered to the heart and brain ...neither...so gently as to produce no effect, or so violently as to cause mischief... [these shocks] should be transmitted through every part of the body, but more particularly through the diaphragm and intercostal muscles; the heart, the brain, and the spinal marrow". ${ }^{6}$ Fothergill added that, after every other attempt to inflate the lungs had failed, tracheostomy was the last option. ${ }^{9}$

\section{Most of the things worth doing in the world had been de- clared impossible before they were done. Louis B. Brandeis}

\section{MID-LATE $19^{\mathrm{TH}}$ CENTURY}

It was the advent of widespread use of general anesthesia in the 1840s that altered the course of medical history and brought to light the action of jaw advancement and tongue extension. No longer were stillbirth and drowning the main causes of death by asphyxia; it was now the medical community and their use of general anesthesia that was at fault.

Discovered by Joseph Priestly in 1776, nitrous oxide was used recreationally by the British upper class as early as 1799 to cause euphoria and slight hallucinations. ${ }^{16} \mathrm{Sir}$ Humphry Davy first described the use of nitrous oxide as a general anesthetic in $1800 .{ }^{17-19}$ Sulfuric ether, described in scientific treatises as early as 1550 , was well known by chemists, pharmacists, and physicians in the late 18th century. ${ }^{20}$ In 1818, Michael Faraday described the great resemblance between the effects of the vapor of ether and nitrous oxide. ${ }^{17,21}$ By the 1830 s, social use of ether and nitrous oxide as excitatory drugs was common and showmen traveled the countryside demonstrating their use. G. Q. Colton was 
one such showman and during a demonstration in Connecticut in 1844, ${ }^{22}$ he introduced Horace Wells, DMD to the use of nitrous oxide. ${ }^{18}$ Wells asked Mr. Colton to come to his office and administer nitrous oxide for the dentist's own molar extraction, ${ }^{23}$ which was described as a painless procedure. Wells' knowledge of nitrous oxide and ether was related to his student William Morton, DMD who, in a collaboration with John Collins Warren, MD, presented the first successful demonstration of general anesthesia at Massachusetts General Hospital on October 16, 1846. ${ }^{24}$ This demonstration was the catalyst that led to the revolution of general anesthesia use worldwide. Within a few days of its being used in London, ether anesthesia was administered in a surgical case in Paris. On January 19, 1847, 1 month after the first continental application of ether for the prevention of pain, Dr. James Young Simpson in Edinburgh used it for making childbirth pain free. ${ }^{17}$ (p 19), 25 Rapid dissemination of this technique for removing pain was astonishing. This explosion in the use of general anesthesia was met with steep opposition in many circles because of the high number of fatalities. Despite this, its use in medicine was widespread by $1847 .{ }^{17(\mathrm{p} 19)}$ Chloroform (not a flammable gas, as was ether, a major advancement in a time of gas lighting) was in medicinal use as early as $1831,{ }^{20,26}$ but it was expensive and did not come into general use as an anesthetic for some years. Although frequently used in England, Massachusetts General Hospital forbade the use of chloroform until 1854 and ether remained the anesthetic of choice in Italy, France, and the US for years to come. ${ }^{17}$ (p 23)

Concern about death secondary to general anesthesia was reported simultaneously with the advent of widespread general anesthesia. A report of a young lady in Newcastle, England, who died during a procedure to remove her toenail was published in $1847 .{ }^{27}$ Letters to the editor of the journal Lancet suggested that her death was secondary to a stimulant (brandy) introduced into her mouth in an attempt to revive her, or that she had suffered from the shock of the operation, syncope, or chloroform poisoning. Early deaths from asphyxia were blamed on the direct action of the anesthetic on the heart, brain, or by "combining with the blood", ${ }^{17,28}$ unrelated to airway obstruction or other remediable causes.

Mouth-to-mouth resuscitation and the use of bellows fell out of favor with erroneous reports of lung tissue damage in the early 19 th century. ${ }^{7}$ The subsequent change to external body movement used various techniques of arm movements and body positions to cause expansion of the rib cage, thus inducing inspiration. Dr. Leroy d'Etoilles wrote a paper about an early technique in $1829 .{ }^{5}$ Marshall Hall introduced the "Ready Method" [Fig. 1] in 1856; ${ }^{29}$ the Sylvester technique followed almost immediately in 1858. ${ }^{30,31}$ [Fig 2. $]^{\text {a }}$ Although each developer of a technique had a following, Henry Robert Silvester seemed to find the widest audience. These mechanical methods of resuscitation continued in use for almost 100 years. Among these innovators was a French physician, J.V. Laborde, who in 1891 developed a repetitive tongue traction method rather than using gross limb movement. Laborde used his technique in stillborn infants, but stated that, if his method did not work, the rescuer should try the Silvester method. ${ }^{32}$ It was not until some 60 years later that that James Otis Elam demonstrated that mouth-to-mouth ventilation was effective and far superior to those manual artificial methods. ${ }^{14 \mathrm{~b}}$

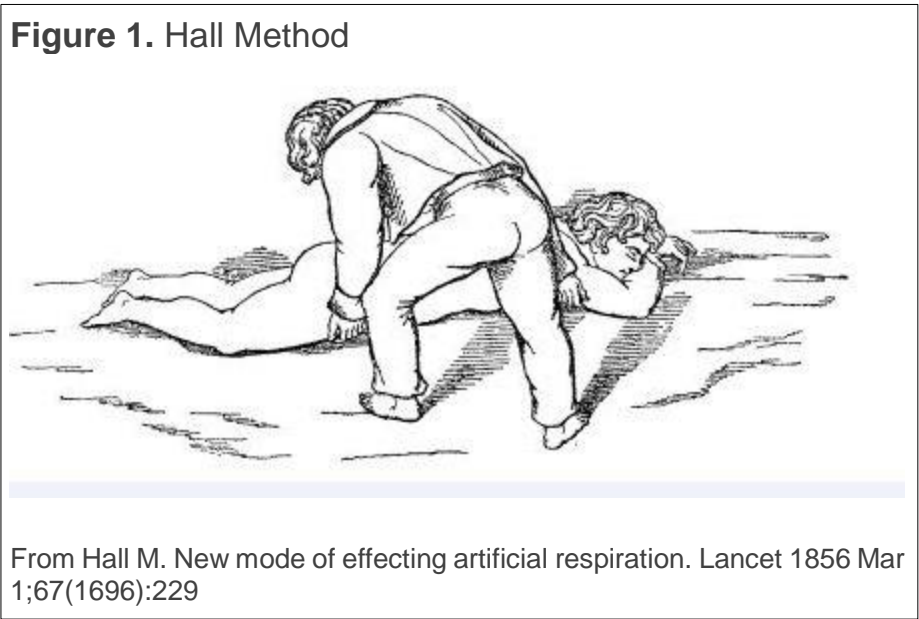

It was Marshall Hall who, in 1856, voiced additional procedural concerns when discussing manual methods for resuscitation of drowning victims. "The term Asphyxia, ought to be exchanged for Apnoea" he stated. ${ }^{33}$ "It is evident that artificial respiration is to the blood-poisoning asphyxia [carbon dioxide build-up was thought to be the cause of death] what the stomach pump is to poison in the stomach". "But there is an Impediment to artificial respiration never before pointed out. It is the obstruction of the glottis or the entrance to the windpipe, in the supine position by the tongue falling backwards and carrying with it the epiglottis-an event which can only be remedied by adopting the prone position;" 29 then rolling the victim onto the side, rocking the patient back and forth. Thus, the possibility of airway obstruction by the tongue had been

scious. ${ }^{\mathrm{b}}$ The Draeger Pulmotor was the harbinger of modern intermittent positive pressure ventilation (IPPV); this mechanism did not move to the operating room until the middle of the $20^{\text {th }}$ century. Used in the operating room for fewer than 30 years, IPPV moved into the world of sleep medicine in 1981 as continuous positive airway pressure (CPAP) for the treatment of obstructive sleep apnea (OSA). 


\section{Figure 2. Silvester's Method}

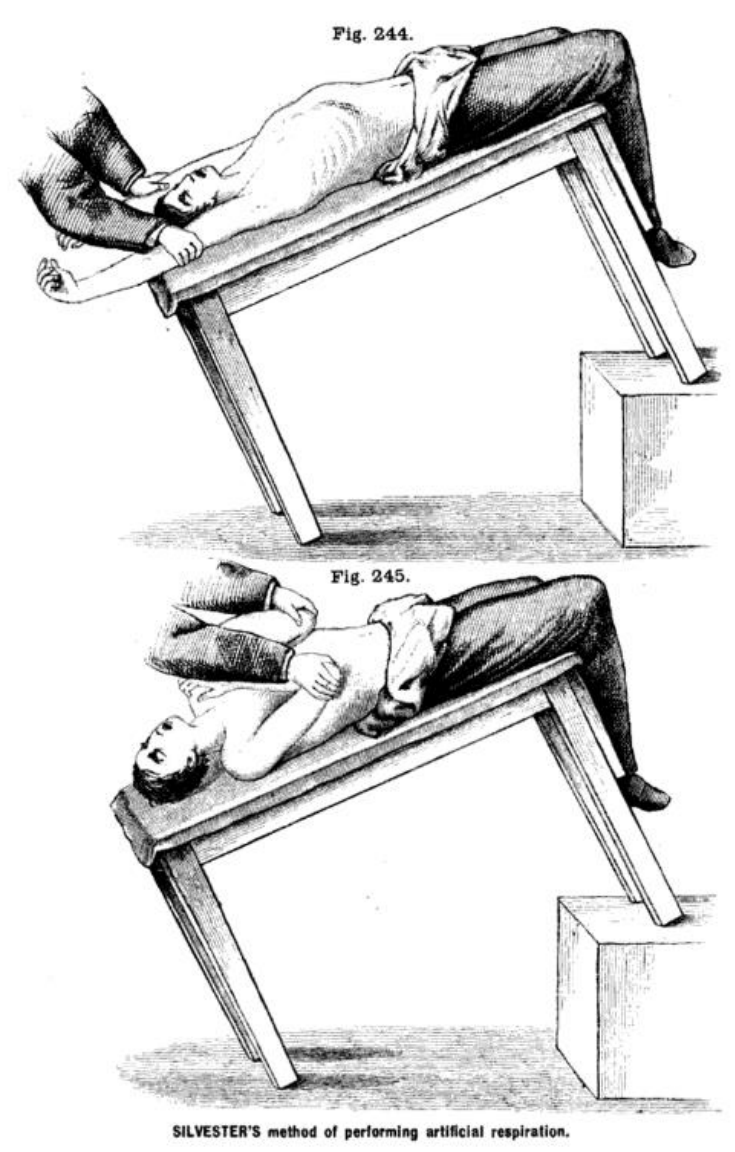

From von Esmarch. The surgeon's handbook on the treatment of wounded in war: a prize essay. New York: Schmidt; 1878.

https://books.google.com/books?id=01XLlqbopq4C\&dq=the\%20surgeon's\%20handbook\&pg=PP3\#v=onepage\&q=the\%20sur-

geon's\%20handbook\&f=false. Accessed December 27, 2018. (Available on Google Books).

acknowledged in the medical literature as early as $1856 .^{c}$

In 1860, Joseph Lister wrote a chapter on chloroform anesthesia for Timothy Holmes' surgical textbook. In this article he reported that airway obstruction may not be caused only by the tongue relapsing into the airway, but also by the unexpected folding of the epiglottis. He recommended that, when clear respiration was impeded, the tongue should be grasped with artery forceps and be drawn firmly forward ${ }^{34}$ to open the obstructed airway. Five years later, E.A. Clarke, MD wrote an article on another case of

\footnotetext{
${ }^{\mathrm{c}}$ The Greek roots for asphyxia, a term coined in 1706, is "cessation of a pulse"; the implication that it is synonymous with suffocation first appeared in $1778 .^{\mathrm{c}}$ Asphyxia became the term associated with a lack of oxygen that leads to unconsciousness and death if not immediately treated. The term apnea, meaning "without breath", was first used in 1719, and implied an intermittent or temporary cessation of breathing either voluntary or involuntary. From:www.dictionary.com/brouse/asphyxia.
}

death from the administration of chloroform. When the patient ceased breathing, "he was immediately placed upon his back with his head lowered, and cold water was dashed upon his face and chest, with the effect of causing three or four long inspirations, without however, affecting the circulation in the least. We then commenced a vigorous artificial respiration, at the same time withdrawing the tongue from the mouth and elevating the epiglottis with the finger". ${ }^{35}$ When Lister's chapter on chloroform anesthesia was published in the 1871 edition of Holmes' surgical textbook, ${ }^{36}$ Lister added that the tongue frequently falls back during chloroform anesthesia and becomes a mechanical impediment to respiration... and the tongue advancement mechanism of action does not appear to be solely mechanical, but also acts through the nervous system. He went on to recommend that the obstruction is easily overcome by pulling the beard or fold of skin below the chin to act on the tongue through the muscle fibers attached to the maxilla [mandible] or by turning the head to the side. ${ }^{37}$ J.T. Clover, a British dentist, responded to Lister's account that he had never had to seize the tongue with artery forceps and that the retropositioning of the tongue was merely due to an "act of swallowing imperfectly performed." ${ }^{38} \mathrm{He}$ had, however, seen partial obstruction of the larynx, "where the mere depressing or raising of the chin was enough to close or open the passage." 39 Clover added in other publications that he "would not advise tracheostomy in such a case, but trust to artificial respiration by Silvester's method. Although this would be useless whilst the glottis is closed." 39 Within a very short time of the advent of general anesthesia, tongue extension, jaw thrust, head tilt, or moving the head to a lateral position as ways of opening an obstructed airway became well known in the field of anesthesia.

Worldwide exposure to these concepts came with the 1877 publication of the Handbuch der Kriegschirurgischen Technik. Eine gekrönte Preisschrift ${ }^{40}$ by Friedrich von Esmarch [Fig. 3], hailed as the most important textbook of surgical procedure ever written. ${ }^{\mathrm{d}}$ He graduated from medical school in 1848 just as ether and chloroform anesthesia revolutionized surgical treatment, making the study of surgery very appealing. After graduation, he visited England and Scotland and was an early convert to Lister's antiseptic technique. ${ }^{41}$ Written for a prize offered by the Empress Augusta Viktoria on the occasion of the Vienna Exhibition in $1877,{ }^{42}$ this text was translated into English within 1 year. ${ }^{43}$ The book included extensive instructions

Online Etymology Dictionary 2010 Douglas Harper. Last accessed Aug 23, 2010 and Webster's Ninth New Collegiate Dictionary. Springfield, Massachusetts: Merriam-Webster;1985 ${ }^{d}$ von Esmarch used his experience on the battlefield (Schleswig-Holstein Wars of 1848-1851 and Second Schleswig-Holstein War of 1864 as well as the Franco-Prussian War 18701871 ) and interaction with other physicians in correspondence and visits, to create the most up-to-date handbook for surgical technique and operations on the battlefield. 
Figure 3. Friedrich August von Esmarch (from his obituary in the British Medical Journal)

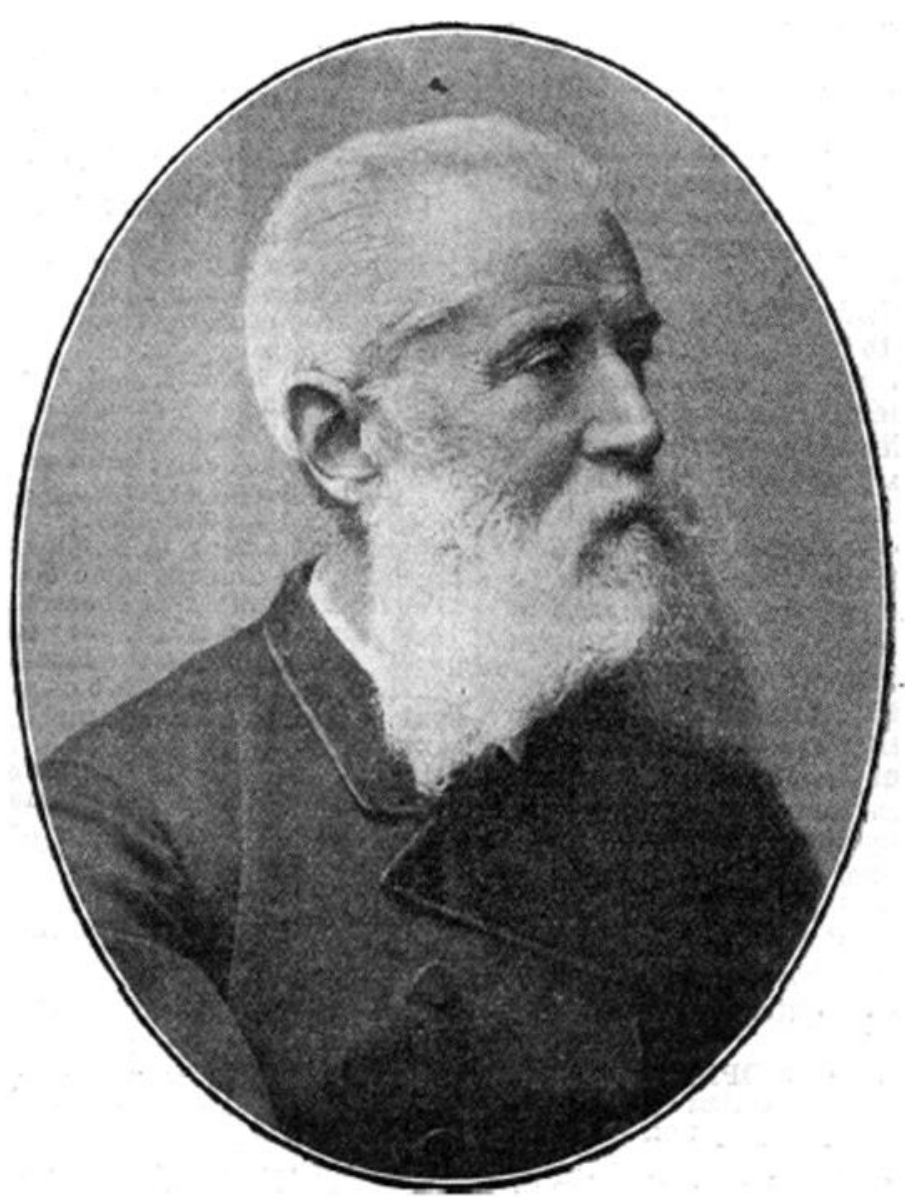

Reproduced from His excellency Johann Friedrich August von Esmarch. Br Med J. 1908;1:719 with permission from BMJ Publishing Group Ltd.

that explained how to deal with patients who had suffered airway closure secondary to chloroform anesthesia. In it, he explains that after the glottis closes and there is "spasm of the muscles of the larynx and tongue, prompt action is now imperative to free the upper entrance to the larynx. The jaws must be separated, the tongue must be drawn well out of the mouth." ${ }^{43}$ In a second scenario, he describes a typical jaw-thrust maneuver, stating one must "apply both hands to the neck in such a manner that the forefingers come to lie behind the ascending rami of the lower maxilla [mandible]; push the whole lower jaw forward until the lower row of teeth projects beyond the upper"e. [Fig. 4.] This second maneuver von Esmarch credited to the British dental surgeon J.S. Little, who in 1866 visited him in Kiel, Germany prior to leaving for India in $1868 .{ }^{44}$ von Esmarch also endorsed the Silvester technique of artificial respiration, helping it to become that most the widely used form
Figure 4. Illustration of maneuvers to open an obstructed airway

Fig. 242.

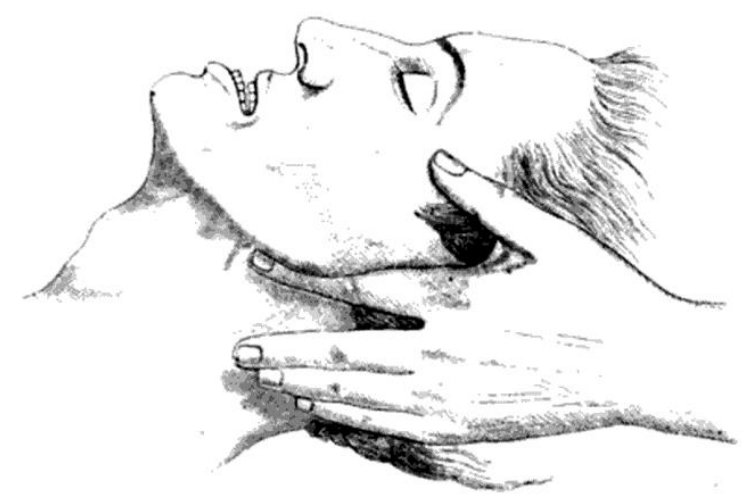

Pushing forward the lower jaw for threatening asphyxia in chloroform narcosis

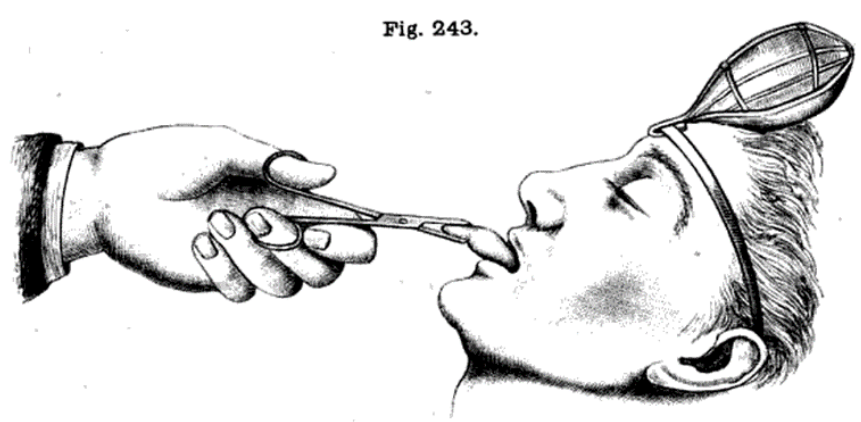

Drawing out the tongue for threatening asphyxia.

From von Esmarch. The surgeon's handbook on the treatment of wounded in war: a prize essay. New York: Schmidt; 1878. https://books.google.com/books?id=01XLlqbopq4C\&dq=the\%20surgeon's\%20handbook\&pg=PP3\#v=onepage \&q=the\%20 surgeon's\%20handbook\&f=false. Accessed December 27, 2018. (Available on Google Books).

of manual artificial respiration. ${ }^{44}$

\section{0 ${ }^{\text {TH }}$ CENTURY}

Ether and chloroform anesthesia continued to be given by open dropper administration until well into the 20th century. ${ }^{45}$ Mechanically assisted ventilation for use during a surgical procedure was not developed until the mid 20th century. ${ }^{46}$ In the intervening century, physicians had to temper their use of anesthetics to maintain a patient's spontaneous breathing. Thus, the need to understand techniques that open the airway of a patient with an obstruction under general anesthesia was part of the training for every medical practitioner.

Marshall Hall, in his paper on the resuscitation of

\footnotetext{
${ }^{\mathrm{e}}$ The jaw-thrust maneuver is closely tied to von Esmarch's textbook and, on the continent, is often referred to as Esmarch maneuver.
} 
drowning victims in 1856 , was the first to state, whether truthfully or not, that "in the supine position, the tongue falls backwards and closes the glottis. All inspiration is therefore impossible. In the prone position, the tongue falls forwards, and leaves the glottis freely patent. Inspiration is therefore possible." ${ }^{29}$ Research about the effect of passive head and jaw position on airway obstruction continues. In 1959, Safar et al. studied airway obstruction in unconscious, spontaneously breathing patients to determine the effect of passive maneuvers, e.g.: body position (prone or supine), head position (flexed or extended) and jaw position (supported forward manually or left alone), and the effect of these maneuvers on airway patency. Complete airway obstruction developed in all of his subjects when the head was flexed regardless of body or head position; in none of the subjects did airway obstruction develop with head extension and mandibular support in a protrusive position. ${ }^{47}$ Similar passive movements were studied by Isono in $2003^{48}$ and currently, a research group in Amsterdam continues to study the effect of passive maneuvers on the airway. ${ }^{49}$ Physicians had more than a century of knowledge on the success of jaw thrust in opening an occluded airway when OSA syndrome was first described in the medical literature in $1973 .{ }^{50}$ The deep-rooted knowledge of the effectiveness of jaw-thrust maneuver and tongue extension provided all the background required for future development of noninvasive therapy for OSA with OAT.

\section{CONCLUSION}

The development of general anesthesia created an environment in which several thousand people risked asphyxia and the number of people with airway obstruction was greatly increased beyond the number of drowning victims and stillborn births. Knowledge about tongue relapse in those who were unconscious was acknowledged by the mid 19th century and the medical field united to find solutions to airway obstruction. The knowledge that the tongue could be moved bodily forward with a forceps or a towel, and the entire mandible could be moved forward by pushing on the distal border of the rami or simply extending the entire head resulted in resolution of airway obstruction was advanced early. Although the actual mechanics were still in question, all the knowledge was in place to be used after OSA had been defined as a disease related to upper airway obstruction during sleep. Physicians were the first to call for oral appliances to hold the tongue or jaw forward and dentists were in the best position to fabricate this new treatment modality. Thus, 200 years of medical experiments, education, and discussions led to the development of OAT for OSA.

\section{If you want to understand today, you have to search yes- terday. \\ Pearl S. Buck}

The next segment on the history of OAT will look at orthodontic therapy and the evolution of knowledge and advancement of dental techniques from 16th to the 20th centuries that led to development of the first modern oral appliances for the treatment of OSA in 1982-1983.

\section{ACKNOWLEDGMENTS}

I would like to thank Alice C. Grover for her assistance in completing this manuscript.

\section{ABBREVIATIONS}

CPAP: Continuous positive airway pressure

IPPV: Intermittent positive pressure ventilation

OAT: Oral appliance therapy

OSA: Obstructive sleep apnea

\section{REFERENCES}

1. Jewson D., N. (1974). Medical Knowledge and the Patronage System in 18th Century England. Sociology, 8(3), 369-385. https://doi.org/10.1177/003803857400800302

2. Fox, N. J. (1988). Scientific theory choice and social structure: the case of Joseph Lister's antisepsis, humoral theory and asepsis. History of Science, 26(4), 367-397

3. Manderson, L. (1987). Hot-cold food and medical theories: overview and introduction. Social Science \& Medicine, 25(4), 329-330

4. The Holy Bible, New Century Version. Nashville, TN: Thomas Nelson; 1984.

5. Karpovich PV. Adventures in Artificial Respiration. New York: Association Press; 1953

6. Kite C. An essay on the recovery of the apparently dead. London: C. Dilly in the Poultry;1788. Accessed by Hathi Trust Aug 20, 2018

7. Baker AB. Artificial Respiration, The history of an idea. Med Hist. 1971 Oct 15;(4):336-351

8. Tossach W. A man dead in appearance, recovered by distending the lungs with air. In Medical essays and observations revised and published by a society in Edinburgh. Vol Y. Part II pg. 605: Edinburgh 1744. $\quad$ p. 605-608. Available at: https://books.google.com/books?id=DrYMgZM1YZgC\&pg=PA605

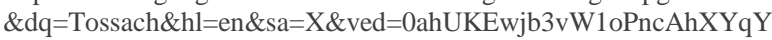
MKHTCNCK8Q6AEIWzAJ\#v=onepage \& $\mathrm{q}=$ Tossach\& $\mathrm{f}=$ false Last accessed August 20, 2018

9. Elliot J.A. A complete collection of the medical and philosophical works of James Fothergill. 1781. London: John Walker;1781 p 110-1

10. Banerjee S. History of tracheostomy. Indian J Otolaryngol Head Neck Surg. 1996 Oct-Dec;47(4):262-5

11. Musso CG. Imhotep: The dean among ancient Egyptian physiciansAn example of a complete physician. Humane Medicine 2005:5(1):169-171

12.

Szmuk P, Ezri T, Evron S, Roth Y, Katz J. A brief history of tracheostomy and tracheal intubation, from the Bronze Age to the Space Age. Intensive Care Med. 2008;34(2):222-228

13. Sittig SE, Pringnitz JE. Tracheostomy: Evolution of an airway. AARC Times. $2001 \mathrm{Feb} ; 25(2): 48-51$ 
14. Webb RT, Bacon D. History of resuscitation. Int Anesthesiol Clin. 2017 Summer;55(3):117-129

15. Flagg PJ. The art of resuscitation. New York: Reinhold Publishing Corp;1944 p.8

16. Nitrous Oxide. https://en.wikipedia.org/wiki/Nitrous_oxide. Wikipedia. Last accessed Aug. 20, 2018

17. Snow J. On chloroform and other anesthetics: Their action and administration. London: John Churchill; 1858.

18. Boyle HEG. Nitrous oxide: history and development. Br Med J. 1934 Jan 27;1(3812):153-155

19. Davy H. Researches, chemical and philosophical: chiefly concerning nitrous oxide, or dephilogisticated nitrous air and its respiration. London: J. Johnson;1800 https://books.google.com/books/about/Researches_Chemical_and_Philosophical_Ch.html?id=jhU-

AAAAAQAAJ\&printsec=frontcover\&source $=$ kp_read_button\#v=onepage\&q\&f=false Accessed Aug 21, 2018

20. Jackson CT. A manual of etherization containing directions for the employment of ether, chloroform and other anesthetic agents, by inhalation. Boston: J.B. Mansfield;1861

21. Faraday M. Some experiments and observations on a new acid substance. [Article V.] Quarterly Journal of Science and Arts. No V. Vol III. New York: Eastburn\& Co; 1818. Hathitrust. https://babel.hathitrust.org/cgi/pt?id=mdp.39015059725336; view=1 up;seq=7 Accessed Aug 21, 2018

22. Sims JM. The Discovery of Anaesthesia. Article III. Gorgas FJS and Hodgkin JB Eds. American Journal of Dental Science. Vol II-third series. Baltimore: Snowden \& Cowman ;1878

23. Wells H. A history of the discovery of the application of nitrous oxide gas, ether and other vapors to surgical operations. Hartford: J. Gaylord Well;1847. P. 6-8

24. William T. G. Morton. Wikipedia. https://en.wikipedia.org/wiki/William_T._G._Morton. Last accessed Aug 20, 2018

25. Simpson JY. On a new anaesthetic agent, more efficient than sulphuric ether. The Lancet. 1847. 50:549-550.

26. Guthrie S. New mode of preparing a spirituous solution of chloric ether. American Journal of Science and Arts. 1832. 21;64-65:405-8. https://books.google.com/books?id=iuzRAAAA-

MAAJ\&pg=PA64\#v=onepage\&q\&f=false accessed Aug 21, 2018

27. Simpson JY. The alleged case of death from the action of chloroform. Lancet. Feb 12 1848;51(1276):175-176

28. Snow J. The fatal choloroform case at Newcastle (correspondence). Lancet 1848 Feb 26; 9(1):239.

29. Hall M. New mode of effecting artificial respiration. Lancet 1856 Mar 1;67(1696):229

30. Silvester HR. A new method of resuscitating still-born children, and of restoring persons apparently drowned or dead. Br Med J. July 17 $1858 ; 2: 576$

31. Silvester HR. Treatment of asphyxia. Lancet. 1858 June 19;71(1816):616

32. Laborde JV. Sur un nouveau moyer de remédier à la mort apparente par submersion. Bulletin Médical. Sixieme Année 1892 Paris Bureaux: 82 rue des Mathurins, 82 ; 1044-1045

33. Hall M. Asphyxia, its rationale and its remedy. Lancet. Apr 12 1856;56:393-394

34. Lister J. Chloroform. In T Holmes editor. A system of surgery Theoretical and Practical in Treatises by various authors. London: Parker, Son and Bourn; 1862 p 101

35. Clark EA. Case of death from the administration of chloroform. In Piggot AS, Gorgos FJS, editors. American Journal of Dental Science Vol 2. Baltimore: Snowden and Cowan. London: Trubner and Co, 1867

36. in Treatises by various authors Vol. 5. Ed. T Holmes. London: Longmans, Green and Co.1871 p 499.

37. Lister J. Operative and Minor Surgery. In: Holmes T. editor. A system of surgery Theoretical and Practical in Treatises by various authors. Part V. $2^{\text {nd }}$ edition. London: Longmans, Green and Co. 1871. p 535.

38. Clover JT. Chloroform Accidents. Br Med J. July 8, 1871 p33

39. Clover JT. On the administration of chloroform in dental operations. (Abstract) The British J of Dental Science Vol XI. Jan-Dec, 1868 London: John Churchill \& Sons, New Burlington Street. P. 123-141 (Available on Google $\quad$ Books) https://books.google.com/books?id=_PoaAQAA-

MAAJ\&pg=PP7\&dq=The+British+Journal+of+Dental+Sci-

ence+Vol+XI,+January-December,++1868 .+Lon-

don:+John+Churchill+\%26+Sons,+New+Burling-

ton+st.\&hl=en\&sa=X\&ved=0ahUKEwivlemTjPrcAhVH6oM-

KHWcgD-8Q6AEIKTAA\#v=onepage\&q=The\%20British\%20Journal $\% 20$ of $\% 20$ Dental $\% 20$ Science $\% 20 \mathrm{Vol} \% 20 \mathrm{XI} \% 2 \mathrm{C} \% 20 \mathrm{January}-$

December\%20\%2C\%201868.\%20Lon-

don\%3A\%20John\%20Church-

ill $\% 20 \% 26 \% 20$ Sons $\% 2$ C $\% 20$ New $\% 20$ Burlington $\% 20$ st.\&f=false Last accessed Aug 20, 2018

40. Esmarch F. Handbuch der Kriegschirurgischen Technik. Eine gekrönte Preisschrift. Hannover: Carl Rümpler; 1877

41. Herzenberg JE. Johann Freidrich August von Esmarch: his life and contributions to orthopaedic surgery. Iowa Orthop. l1988;8: 85-91

42. Friedrich von Esmarch. Wikipedia. https://en.wikipedia.org/wiki/Friedrich_von_Esmarch Accessed Aug 21, 2018

43. von Esmarch F. The surgeon's handbook of the treatment of wounded of war. A prize essay. Trans: Clutton HH and Cantar BA. Hanover: Charles Rümpler;1878 p. 116

44. Defalque RJ, Wright AJ. Who invented the "Jaw Thrust"? Anesthesiology 2003;99(6)1463-464

45. Chang CY, Goldstein E, Agarwal N, Swan KG. Ether in the developing world: rethinking an abandoned agent. BMC Anesthesiol. 2015;15(1):149. doi:10.1186/s12871-015-0128-3

46. Slutsky AS. History of Mechanical Ventilation from Vesalius to Ventilator-induced lung injury. Am $J$ Resp Crit Care Med. 2015;191(10):1106-1114

47. Safar P, Escarraga LA, Chang F. Upper airway obstruction in the unconscious patient. J Appl Physiol. 1959;14(5):760-764

48. Isono S, Tanaka A, Tagaito $\mathrm{Y}$, et al. Influences of head positions and bite opening on collapsibility of the passive pharynx. J Appl Physiol. 2004 July;97(1):339-346

49. Vonk PE, Beelen AMEH and de Vries N. Towards a prediction model for drug-induced sleep endoscopy as selection tool for oral appliance treatment and positional therapy in obstructive sleep apnea. Sleep Breath. Epub 2018 Mar 9

50. Guilleminault C, Eldridge FL and Dement WC. Insomnia with sleep apnea: a new syndrome. Science. 1973 Aug 31;181(4102):856-858

\section{SUBMISSION AND CORRESPONDENCE INFORMATION}

\section{Submitted in final revised form September 2, 2018 Accepted for publication November 8, 2018}

Address correspondence to: B. Gail Demko, DMD, 6409 Prairie Dunes Drive, Grand Blanc, MI 48439, Email: bdemko@yahoo.com 
The author has no financial conflicts of interest to disclose.

\section{APPENDIX}

\section{Major Innovators:}

Bretonneau, Pierre-Fidèle (1778-1862)

Clarke, E.A. (19 ${ }^{\text {th }}$ century)

Clover, Joseph Thomas (1825-1882)

Colton, G.Q. (1814-1898)

Davy, Humphry (1778-1829)

Elam, James Otis (1918-1995)

D’Etoilles, Leroy (1798-After 1855)

Faraday, Michael (1791-1867)

Fothergill, John (1712-1780)

Hall, Marshall (1790-1857)

Hooke, Robert (1635-1703)

Kite, Charles (1760?- 1811)

Laborde, J. V. (early-mid $19^{\text {th }}$ cent-1903)

Lister, Joseph (1827-1912)

Little, J.S. (19 th $^{\text {century })}$

Morton, William T. G. (1819-1868)

Paracelsus (1493-1541)

Priestly, Joseph (1733-1804)

Silvester, Henry R. (1829-1908)

Snow, John (1863-1858)

Tossach, William (1700-1771)

Von Esmarch, Friedrich (1823-1908)

Wells, Horace (1815-1848)

Warren, John Collins (1778-1856)
French physician

British physician

British dentist and anesthesiologist

American showman, former medical student

British chemist and inventor

American physician and respiratory researcher

French surgeon

British scientist and physicist

British physician, botanist

British physician, physiologist and anatomist

British physician and physiologist

English physician, surgeon and scientist

French physician and physiologist

British physician and pioneer of antiseptic surgery

British surgeon

American dentist

Swiss physician, alchemist and astrologer

British theologian, chemist, philosopher, educator

British physician

British physician and anesthesiologist

British physician and physiologist

German physician, surgeon

American dentist

American surgeon 